\title{
Effect of Shear Reinforcement on Flexural Strengths of Normal Weight and Palm-Kernel Shell Reinforced Concrete Beams
}

\author{
Lekan Makanju Olanitori $^{1}$ and Jeremiah Ibukun Okusami ${ }^{2}$
}

\begin{abstract}
The focus of this research is to investigate the effect of shear reinforcement on flexural capacities of reinforced Normal Weight Concrete (NWC) and Palm Kernel Shell Concrete (PKSC) beams. Ten beams were cast: five from PKSC and five from NWC. The beams were with shear reinforcement spacing of $50 \mathrm{~mm}, 100 \mathrm{~mm}, 150 \mathrm{~mm}, 200 \mathrm{~mm}$ and without shear reinforcement respectively. The beams were loaded with a point load at beam centre, and the results showed that the flexural capacity of the beams decreases as the spacing of the shear reinforcements increases. The ultimate loads of PKSC beams were lesser than that of NWC beams by $9.0 \%, 7.1 \%, 14.5 \%, 21$ and $26.8 \%$ for shear reinforcement spacing of $50 \mathrm{~mm}, 100 \mathrm{~mm}, 150 \mathrm{~mm}, 200 \mathrm{~mm}$ and for beam without shear reinforcements respectively. The deflections of the PKSC beams were greater than that of the NWC, hence the PKSC beams had more plastic rotation capacity than the NWC beams. The study shows that reinforced concrete beams produced from 20\% partial replacement of crushed aggregate by PKS have the potential of being used for structural purposes in low cost buildings.
\end{abstract}

Keywords: Palm Kernel Shell Concrete, Normal weight concrete, Palm kernel shell, Deflection, Shear reinforcement.

\section{Introduction}

Sustainable construction process is aimed at minimising the environmental and worker-related impacts

(CIB and UNEP-IETC, 2002). Construction is the broad process/mechanism for the realisation of human settlements and the creation of infrastructure that supports development. This includes the extraction and beneficiation of raw materials, the manufacturing of construction materials and components, and the construction project cycle from feasibility to deconstruction of built environment (CIB and UNEP-IETC, 2002). The continuous development in construction and neglecting the environmental needs lead to negative impact on the environment and its surrounding (Ling and Gunawansa, 2011; Abidin, 2010). Since the discovery of crude oil in the southern part of Nigeria in the 70s, and its accompanied petrol-dollars, a rapid development in construction sector has been observed in Nigeria, which increases the level of per capita energy consumption (Okusami, 2019). The worldwide building construction sector consumes approximately $40 \%$ of energy produced in the world (Perez-Lombard et al, 2008). Sustainable buildings enhance quality of life, work productivity, and create healthy environment. Therefore, sustainable construction or green buildings has been identified as the response of the building construction sector to the challenge of sustainable 
development (Hoffman and Henn, 2008). The sustainable construction commonly uses green materials, reduces energy consumption, saves water, preserves indoor air quality, and many more (Safinia et al, 2017).

Agricultural wastes have started becoming a major problem if not properly managed. The majority of construction and agricultural wastes, however, are considered inert and can potentially be used as construction materials (Kabir et al, 2016). In Nigeria, the use of the conventional materials such as sand and granite drastically reduce the natural stone deposit and this has damaging effect on the environment causing ecological imbalance (Short and kinniburgh, 1998; Alengaram et al., 2008). The use of waste materials in construction contribute to conservation of natural resource and the protection of our environment (Abdullah 1996; Ndoke, 2006; Osei and Jackson, 2012). Because of its low density, PKS can be used to produce Light Weight Concrete (LWC). Light Weight Aggregate concrete is not a new invention in concrete technology; it has been used since ancient times (Shafigh et al., 2010).

From literature, many researches have been conducted on the possibility of using agricultural waste ashes as partial replacement for cement in the construction industry. Researches have been carried out on partial replacement of cement with Bamboo Leaf Ash (Dwiveldi et al., 2006), partial replacement of cement with Rice Husk Ash (Chungsangunsit et al., 2007), partial replacement of cement with Palm Fruit Ash (Olonode, 2010), partial replacement of cement with Locust Bean Pod Ash (Adama et al, 2013), partial replacement of cement with Cassava Peel Ash (Salau et al., 2012), partial replacement of cement with Corn Husk Ash (Adesanya and Raheem, 2009) and partial replacement of cement with Corn Cob Ash (Akinwumi and Aidomojie, 2015). Also Busari, et al., (2018) carried out research on the possibility of using Bamboo Straw Ash to improve the Index Properties of Lateritic Soil. Also, some researches have been carried out on partial replacement of normal weight aggregate with Oil-Palm-Boiler Clinker (Chai, et al., 2017) and partial replacement of normal weight aggregate with Oil Palm Shell (Aslam, et al., 2017). Shafigh et al (2017, PP 04) investigated the use of Oil-palm-boiler clinker (OPBC) as coarse aggregate instead of conventional coarse aggregates to produce a greener concrete, for this purpose, normal weight coarse aggregates was substituted with dry OPBC aggregates up to $75 \%$ (by volume) in a high strength normal weight concrete.

Azunna (2019), investigated the use of palm kernel shell as a partial replacement for coarse aggregate in concrete. The results show that for a replacement of $10 \%$ and $25 \%$ of PKS gave $4.78 \mathrm{~N} / \mathrm{mm}^{2}$ and $4.44 \mathrm{~N} / \mathrm{mm}^{2}$ compressive strengths respectively. The flexural behaviour of NWC and PKSC under-reinforced concrete beams produced from 30 grade concrete were investigated by Alengaram (2008). The beams were tested under two-point loading for flexure until failure occurred. It was observed that the moment capacity of PKSC beams was higher than NWC beams by about three percent. Also, the mode of failure observed in PKSC was ductile compared to the brittle failure of NWC beams. The PKSC beams exhibited higher deflection under constant load until failure, compared to NWC beams that failed in brittle manner without warning.

Alengaram, et al (2011) studied the shear behaviour of PKSC beams prepared using palm kernel shell (PKS) as lightweight aggregate (LWA). PKSC beam was able to produce twice flexural and shear cracks compared to NWC beam, and tension stiffening between the tensile cracks of PKSC enhanced flexural rigidity and dowel action. Mo et al 
(2014) studied the effect of steel fibre on the toughness characteristics such as flexural toughness, fracture parameters and compressive toughness of steel fibre oil palm shell concrete (SFOPSC). The addition of steel fibres significantly increased both the fracture energy and flexural toughness of the SFOPSC up to 16 times. The compressive toughness of SFOPSC specimens with $0.75 \%$ steel fibre was 6 times higher than the specimens without fibres, and an increase of up to $178 \%, 88 \%$ and $41 \%$ for splitting tensile, flexural and direct tensile strengths, respectively.

Słowik (2014) investigated the shear failure mechanism and shear capacity of reinforced concrete beams without transverse reinforcement, and found that the shear span-to-depth ratio and a beam size are important parameters which significantly affect the failure mode of the investigated beams. Acheampong et al (2016) investigated the influence of beam depth with varying longitudinal reinforcement without shear reinforcement. Test variables were longitudinal reinforcement ratio ( $\varrho_{w}$ varying from 1 to $2 \%$ ) and effective depth of beams (varying from 120 to $265 \mathrm{~mm}$ ) with average compressive strength $\left(f_{c u}\right)=30.3 \mathrm{MPa}$ and shear span to effective depth $\left(a_{v} / d\right)=2.5$. All tested beams failed in shear failure modes and were influenced by the beam depth and amount of longitudinal reinforcement.

\section{Methodology}

The PKS which was used as aggregates were obtained from a palm kernel oil production site along Ondo Road, Akure Nigeria, while the fine aggregate was sourced from borrowed pit in Akure metropolis and the coarse aggregate sourced for the quarry along Akure-Owo road. In this investigation, the PKS were washed with detergent and flushed with portable water (warm) to remove dirt, oil film coating and other impurities which could be detrimental to the concrete.

The concrete mix ratio for this study was $1: 1 \frac{1}{2}: 3$. The PKSC beams were produced with $20 \%$ replacement of crushed granite by palm kernel shell (PKS) as coarse aggregate. The grade of concrete used for the production of the PKSC beams was 8.4 $\mathrm{N} / \mathrm{mm}^{2}$, while that of the NWC beams was $10.4 \mathrm{~N} / \mathrm{mm}^{2}$ respectively. Total number of ten beams were cast, five for PKSC beams, while the remaining five beams were NWC beams. One beam each for PKSC and NWC beams were without shear reinforcement, while the remaining four beams each for PKSC and NWC beams were with shear reinforcement spacing of $50 \mathrm{~mm}, 100 \mathrm{~mm}, 150 \mathrm{~mm}$ and $200 \mathrm{~mm}$ respectively. Table 1 shows reinforcement details for beam types while the beam sections are shown in Figs. 1-5. Two type of beams were designed for testing: beam without shear (W) and beam with shear reinforcement $(\mathrm{S})$.

Table 1: Beam details

\begin{tabular}{lccccc}
\hline Beam ID & $\begin{array}{c}\mathrm{b} \\
(\mathrm{mm})\end{array}$ & $\begin{array}{c}\mathrm{h} \\
(\mathrm{mm})\end{array}$ & $\begin{array}{c}\text { Length } \\
\mathrm{mm}\end{array}$ & $\begin{array}{c}\text { Shear rein. Spacing } \\
(\mathrm{mm})\end{array}$ & $\begin{array}{c}\text { Top/bottom/links } \\
\text { reinforcement. }\end{array}$ \\
\hline B1 $1_{\mathrm{NCS}}$ & 100 & 150 & 1000 & 50 & Y10T/C, Y8L \\
B2 & 100 & 150 & 1000 & 100 & Y10T/C, Y8L \\
B3 & 100 & 150 & 1000 & 150 & Y10T/C, Y8L \\
B4 & 100 & 150 & 1000 & 200 & Y10T $/ \mathrm{C}, \mathrm{Y} 8 \mathrm{~L}$ \\
B5 & 100 & 150 & 1000 & $\mathrm{~W}$ & $\mathrm{Y} 10 \mathrm{~B}$
\end{tabular}




$\begin{array}{lccccc}\text { B1 } 1_{\text {PKS }} & 100 & 150 & 1000 & 50 & \text { Y10T/C, Y8L } \\ \text { B2 } & 100 & 150 & 1000 & 100 & \text { Y10T/C, Y8L } \\ \text { B3 } 3_{\text {PKS }} & 100 & 150 & 1000 & 150 & \text { Y10T/C, Y8L } \\ \text { B4 } & 100 & 150 & 1000 & 200 & \text { Y10T/C, Y8L } \\ \text { B5 } & 100 & 150 & 1000 & W & \text { Y10T }\end{array}$

Where $b$ and $h$ are breadth and height

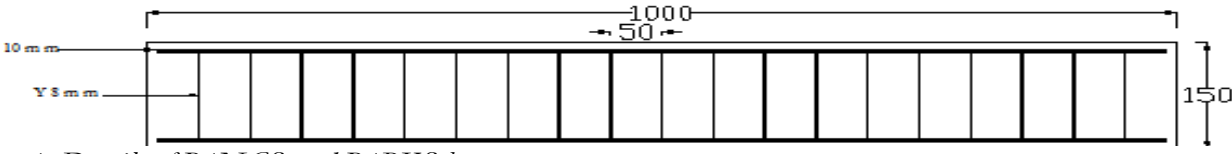

Figure 1: Details of B1NCS and B1PKS beams

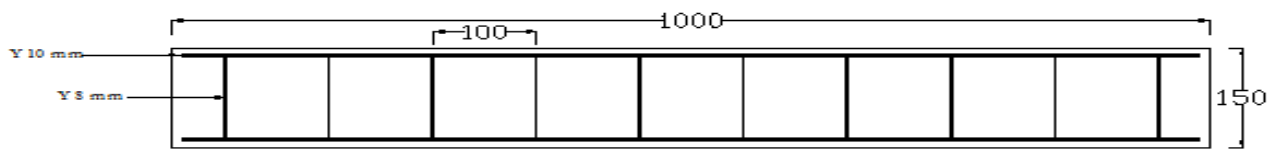

Figure 2: Details of B2NCS and B2PKS beams

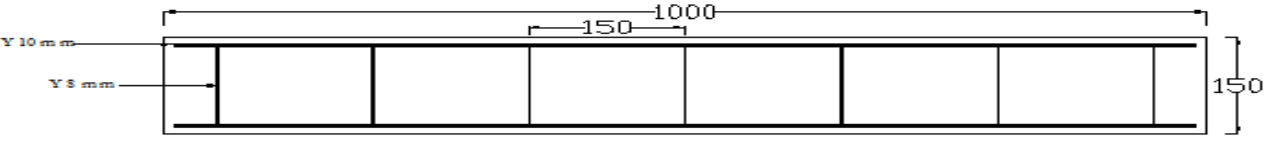

Figure 3: Details of B3NCS and B3PKS beams

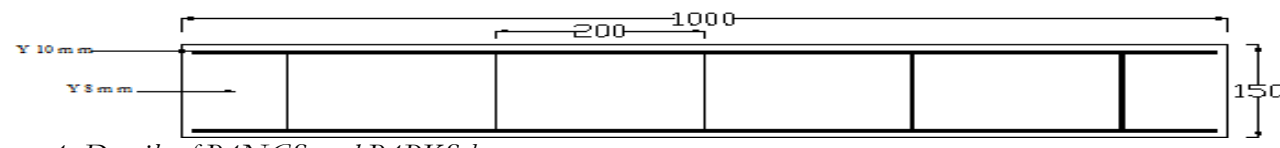

Figure 4: Details of B4NCS and B4PKS beams

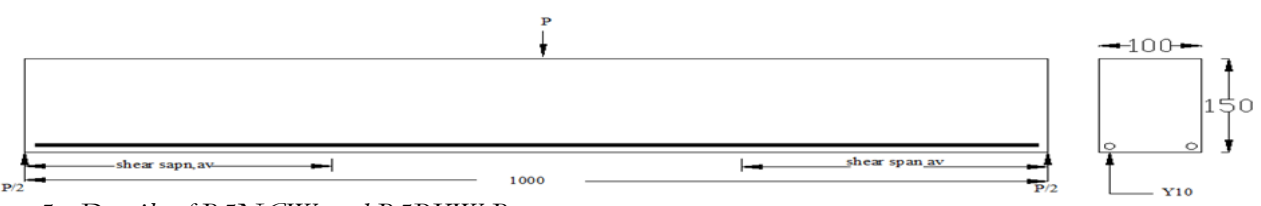

Figure 5: Details of B5NCW and B5PKW Beams

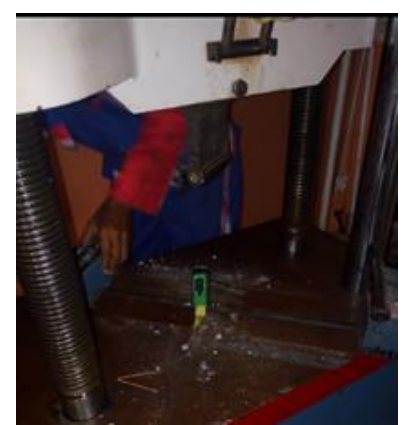

(a): The Universal Testing Machine

Figure 6: Experimetal set-up for all beams type.

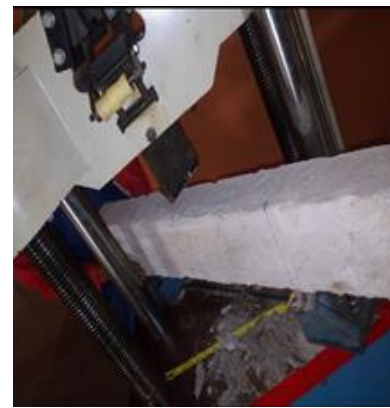

(b): Beam Setting-Up 
The beams were cured by covering them with wet jute bags. The beams were subjected to a Point Load at the centre using Universal Flexural testing machine with a capacity of $300 \mathrm{kN}$ (Figure 6). The effective length of each beam was kept at $750 \mathrm{~mm}$ measured from the center of each support. The flexural strength test set-up was carried out in accordance with BS EN 12390-5(2000). The application of load was done at constant rate and deflection was measured at the beam centre. The beams were loaded until the ultimate load capacity of the beam was reached. These procedure was repeated for all beams type.

\section{Result and Discussion}

The results of the flexural tests carried out on the beams are presented below.

\subsection{Determination of concrete density}

The density of the NWC was determined to be $2500 \mathrm{~kg} / \mathrm{m}^{3}$ while that of PKSC with $20 \%$ replacement of granite by PKS was $24100 \mathrm{~kg} / \mathrm{m}^{3}$ respectively. This shows that PKSC is lighter by $3.6 \%$ when compared with that NWC.

\subsection{Test on beams}

The beam's description, the ultimate failure load, load at first crack and flexural capacity are presented in Table 2 . Figure 7 shows beam set under point load at the centre, while the bending stress can be determined by Eq. 1.

$$
F_{r}=\frac{3 F L}{2 b d^{2}}
$$

Where; $F=$ is the load at the fracture point, $L=i$ is the length of the support span, $b=i$ is the breadth and $d=i$ s the depth.

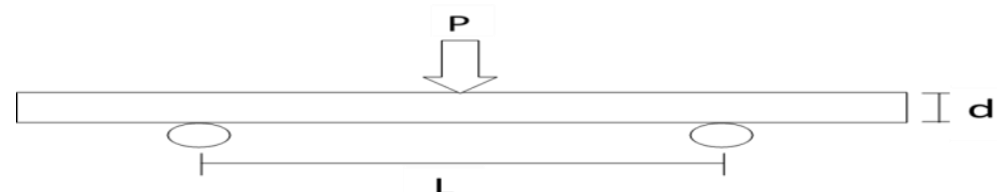

Figure 7: Typical loading of beam at the center with a point load

The results of flexural tests carried out on the beams are presented in Table 2. From Table 2, it can be seen that the ultimate loads for the PKSC beams are lower than that of the NWC beams. This may be attributed to the higher roughness of the surface of granite aggregates and thus a better aggregate interlock and better bonding of the aggregates with the cement paste.

From Table 2, the ultimate loads of the beams decreases as the spacing of the shear reinforcements increases. For beams produced from NWC, the ultimate load was $105.1 \mathrm{kN}, 97.63 \mathrm{kN}, 70.46 \mathrm{kN}, 67.5 \mathrm{kN}$ and $50.16 \mathrm{kN}$ for shear reinforcement spacing of $50 \mathrm{~mm}, 100 \mathrm{~mm}, 150 \mathrm{~mm}, 200 \mathrm{~mm}$ and for beam without shear reinforcements respectively. For beams produced from PKSC, the ultimate load was $96.37 \mathrm{kN}, 91.17$ $\mathrm{kN}, 61.56 \mathrm{kN}, 55.79 \mathrm{kN}$ and $39.57 \mathrm{kN}$ for shear reinforcement spacing of $50 \mathrm{~mm}, 100$ $\mathrm{mm}, 150 \mathrm{~mm}, 200 \mathrm{~mm}$ and for beam without shear reinforcements respectively. From 
Table 2, there were decrease of ultimate loads of PKSC beams when compared with that of NWC beams by $9.1 \%, 7.1 \%, 14.5 \%, 21$ and $26.8 \%$ for shear reinforcement spacing of $50 \mathrm{~mm}, 100 \mathrm{~mm}, 150 \mathrm{~mm}, 200 \mathrm{~mm}$ and for beam without shear reinforcements respectively. Therefore, the more closely the shear reinforcement spacing, the closer the ultimate load of PKSC to that of the NWC.

Figure 8, shows the effect of shear reinforcement on the flexural capacity of the two types of beams, that is, decreasing the shear reinforcement spacing, resulted in higher flexural capacity of the beams.

Table 2: Experimental load at first crack and failure load

\begin{tabular}{|c|c|c|c|c|c|c|c|}
\hline Type & Shear Spacing & Max Force & Load at First Crack & $\mathrm{L}$ & $\mathrm{b}$ & $\mathrm{d}$ & $\begin{array}{c}\text { Flexural capacity } \\
\left(F_{r}\right)\left(\mathrm{N} / \mathrm{mm}^{2}\right)\end{array}$ \\
\hline & $(\mathrm{mm})$ & $\mathrm{kN}$ & $\mathrm{kN}$ & $(\mathrm{mm})$ & $(\mathrm{mm})$ & $(\mathrm{mm})$ & \\
\hline \multicolumn{8}{|c|}{ NWC With Varying Shear Spacing } \\
\hline $\mathrm{B} 1_{\mathrm{NCS}}$ & 50 & 105.01 & 78.28 & 750 & 100 & 150 & 48.815 \\
\hline $\mathrm{B} 2_{\mathrm{NCS}}$ & 100 & 97.63 & 70.62 & 750 & 100 & 150 & 35.23 \\
\hline B3 $3_{\text {NCS }}$ & 150 & 70.46 & 52.08 & 750 & 100 & 150 & 33.8 \\
\hline $\mathrm{B} 4_{\mathrm{NCS}}$ & 200 & 67.6 & 49.15 & 750 & 100 & 150 & 25.08 \\
\hline $\mathrm{B} 5_{\mathrm{NCW}}$ & WS & 50.16 & 37.31 & 750 & 100 & 150 & 10.33 \\
\hline \multicolumn{8}{|c|}{ PKSC With Varying Shear Spacing } \\
\hline $\mathrm{B} 1_{\mathrm{PKS}}$ & 50 & 96.37 & 71.76 & 750 & 100 & 150 & 45.585 \\
\hline $\mathrm{B} 2_{\mathrm{PKS}}$ & 100 & 91.17 & 63.07 & 750 & 100 & 150 & 30.78 \\
\hline B3 ${ }_{\text {PKS }}$ & 150 & 61.56 & 49.15 & 750 & 100 & 150 & 27.895 \\
\hline B4PKS & 200 & 55.79 & 41.64 & 750 & 100 & 150 & 19.785 \\
\hline B5 $5_{\text {PKW }}$ & WS & 39.57 & 29.06 & 750 & 100 & 150 & 7.965 \\
\hline
\end{tabular}

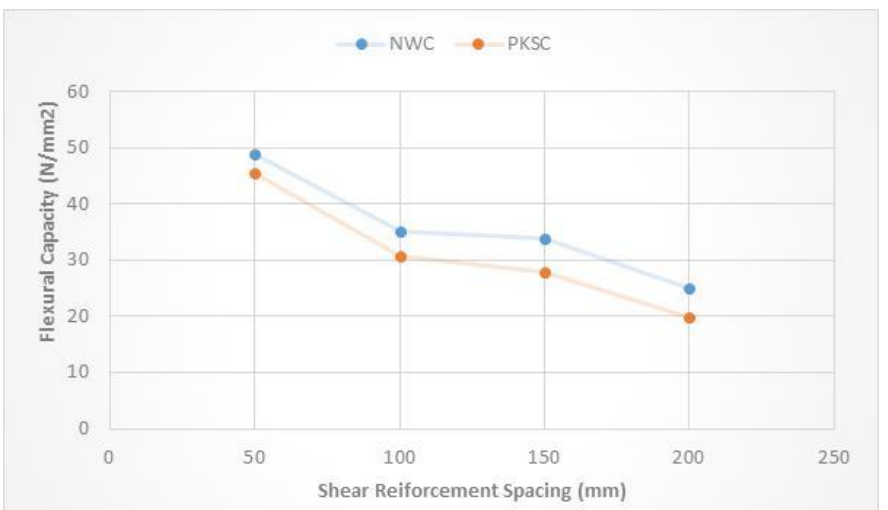

Figure 8: Flexural Capacity for PKSC and NWC beams

Using the equations of the Bristish Standard (BS 8110-1, 1997), the ultimate loads of the experimental beams were estimated. The results of the experimental and estimated ultimate loads for NWC and PKSC beams are presented in Table 3. The estimated loads for beams $\mathrm{B} 5 \mathrm{NCW}$ and $\mathrm{B} 5 \mathrm{PKW}$ were $22.29 \mathrm{kN}$ and $16.48 \mathrm{kN}$ respectively, while the experimental loads were $50.16 \mathrm{kN}$ and $39.57 \mathrm{kN}$ respectively. This shows that for beams without shear reinforcements, the equations of BS 8110-1 (1997) 
underestimated the ultimate load of reinforced concrete beams to the tune of $55.6 \%$ and $58.4 \%$ for NWC and PKSC beams respectively. Also for beams $\mathrm{B} 1_{\mathrm{NCS}}, \mathrm{B} 2_{\mathrm{NCS}}, \mathrm{B} 3_{\mathrm{NCS}}$, and $\mathrm{B} 4_{\mathrm{NCS}}$, there were understimation of the ultimate loads by $49.4 \%, 45.5 \%, 24.5 \%$ and $21.3 \%$ respectively. For beams $\mathrm{B} 1_{\mathrm{PKSC}}, \mathrm{B} 2 \mathrm{PKSC}, \mathrm{B} 3 \mathrm{PKSC}$, and $\mathrm{B} 4 \mathrm{PKSC}$, there were understimation of the ultimate loads by $47.6 \%, 44.7 \%, 18.0 \%$ and $9.6 \%$ respectively. It can be seen that the percentage error in the estimation of the ultimate loads increases with reduction in the shear reinforcement spacing.

Table 3: Experimental and estimated load capacity for beams

\begin{tabular}{ccc}
\hline Beam ID & Experimental load & Estimated load \\
\hline B1 & P $_{\text {AUL }} \mathbf{( k N )}$ & P $_{\text {EUL }} \mathbf{( k N )}$ \\
B1 & 96.37 & 50.45 \\
B2 & 105.01 & 53.17 \\
B2 & 91.17 & 50.45 \\
B3Cs & 97.63 & 53.17 \\
B3 & 61.56 & 50.45 \\
B3 & 70.46 & 53.17 \\
B4 & 55.79 & 50.45 \\
B4 & 67.6 & 53.17 \\
B5 & 39.57 & 16.48 \\
B5 & 50.16 & 22.29 \\
\end{tabular}

\subsection{Deflection Characteristics of Beams}

Deflections of the experimental beams are presented in Table 4. Deflections at the ultimate loads were $15.9 \mathrm{~mm}, 13.5 \mathrm{~mm}, 11.5 \mathrm{~mm}, 7.5 \mathrm{~mm}$, and $6.0 \mathrm{~mm}$ for PKSC beams at loads of $96.37 \mathrm{kN}, 91.17 \mathrm{kN}, 61.56 \mathrm{kN}, 55.79 \mathrm{kN}, 39.57 \mathrm{kN}$ and $15.93 \mathrm{kN}$ respectively, while the deflections at the ultimate loads were $14.5 \mathrm{~mm}, 13 \mathrm{~mm}, 10 \mathrm{~mm}, 6$ $\mathrm{mm}$, and $5.0 \mathrm{~mm}$ for NWC beams at the ultimate loads of $105.01 \mathrm{kN}, 97.63 \mathrm{kN}, 70.46$ $\mathrm{kN}, 67.6 \mathrm{kN}, 50.16 \mathrm{kN}$ and $29.66 \mathrm{kN}$ respectively. The deflections of the PKSC were greater than that of the NWC even at lesser ultimate loads, hence the PKSC beams had more plastic rotation capacity than the NWC beams.

Table 4: Deflection of PKSC and NWC Beams

\begin{tabular}{lcccc}
\hline Shear Spacing $(\mathrm{mm})$ & \multicolumn{2}{c}{$\operatorname{Load}(\mathrm{kN})$} & \multicolumn{2}{c}{ Deflection $(\mathrm{mm})$} \\
\hline & PKSC & NWC & PKSC & NWC \\
B1 $_{\mathrm{PKS}} /$ B1 $_{\mathrm{NCS}}$ & 96.37 & 105.01 & 15.9 & 14.5 \\
$\mathrm{~B} 2_{\mathrm{PKS}} / \mathrm{B} 2_{\mathrm{NCS}}$ & 91.17 & 97.63 & 13.5 & 13 \\
$\mathrm{~B} 3_{\mathrm{PKS}} / \mathrm{B} 3_{\mathrm{NCS}}$ & 67.6 & 70.46 & 11.5 & 10 \\
$\mathrm{~B} 4_{\mathrm{PKS}} / \mathrm{B} 4_{\mathrm{NCS}}$ & 55.79 & 61.56 & 7.5 & 6.0 \\
$\mathrm{~B} 5_{\mathrm{PKW}} / \mathrm{B} 5_{\mathrm{NCW}}$ & 39.57 & 50.16 & 6.0 & 5.0 \\
$\mathrm{~B} 6_{\mathrm{PKP}} / \mathrm{B} 6_{\mathrm{NCP}}$ & 12.06 & 20.66 & 3.1 & 3 \\
\hline
\end{tabular}

From Figure 9, deflections increase with increase in the ultimate loads. Similarly increase in load capacity occurred as a result of decreased shear reinforcement spacing, therefore decreasing the shear reinforcement spacing for both type of beams also lead to increase in deflections. Figure 10 shows the effect of shear reinforcement spacing on the deflections of both NWC and PKSC beams. 


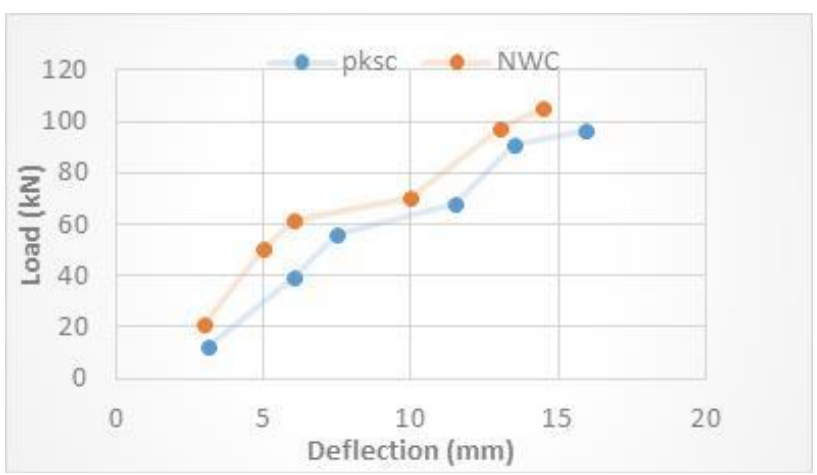

Figure 9: Load-Deflection graph for PKSC and NWC Beam

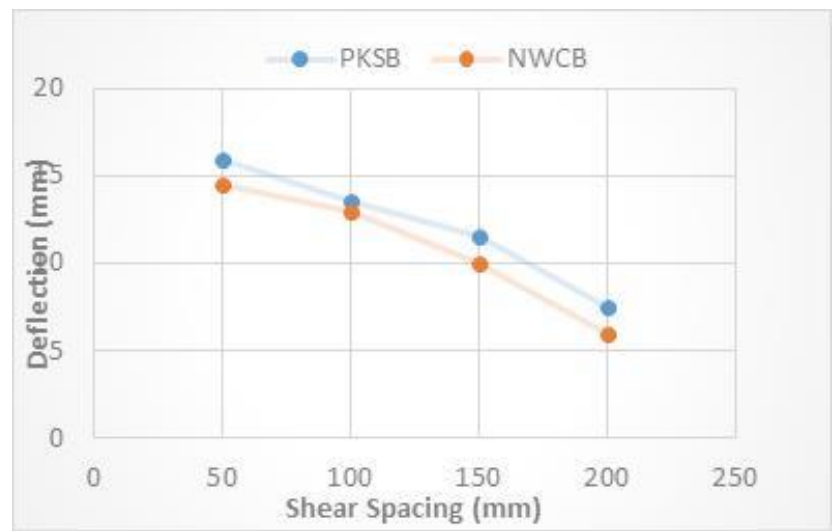

Figure 10: Effect of shear link spacing on deflection of PKSC and NWC Beams.

\section{Conclusion}

From the results and discussions above, the following conclusions can be made: 1. PKSC beams produced by $20 \%$ replacement of NWA with PKS was $3.6 \%$ lighter than NWC beams.

2. PKSC beams behaved similarly to that of the NWC beams.

3. Decreasing the shear reinforcement spacing in both types of beams resulted in the increase in the flexural/load bearing capacity of the beams.

4. Depending on the spacing of the shear reinforcements, decrease of ultimate loads of PKSC beams when compared with that of NWC beams was between $9.1 \%$ and $26.8 \%$.

5. With proper choice of shear reinforcement, PKSC beams can be used for structural purposes in low cost housing units.

\section{Recommendation for Future Research}

Research should be conducted on the effects of cement grade, concrete grade and percentage area of tension reinforcements on the ultimate load of PKS reinforced concrete beams. 


\section{References}

Abdullah, A. A. A. (1996), Palm oil shell aggregate for lightweight concrete. Waste material used in concrete manufacturing, Noyes Publication, pp. 624-636.

Abidin, N. Z. (2010), Investigating the Shear Behaviour and application of sustainable construction concept by Malaysian developers. Habitat International, Vol. 34, Pp. 421-426.

Acheampong, A., Kankam, C. K., and Ayarkwa, J. (2016), Shear behaviour of palm shell reinforced concrete beams without shear reinforcement: Influence of beam depth and tension steel. Journal of Engineering and Construction Technology, Vol. 7, Issue 2, Pp. 8-19.

Adama, A. Y., Jimoh, Y. A, and Kolo, S. S. (2013). Effect of Locust Bean Pod Ash on Compaction Characteristics of Weak Sub Grade Soils. International Journal of Engineering Science Invention, Vol. 2, Issue 1, Pp. 25-30.

Adesanya, D.A., and Raheem, A.A. (2009). A study of the Workability and Compressive Strength Characteristics of Corn Cob Ash Blended Cement Concrete. Construction and Building Materials, Vol. 23, Issue 3, Pp. $311-317$.

Akinwumi, I.I., Aidomojie, O.I. (2015). Effect of Corncob Ash on the Geotechnical Properties of Lateritic Soil Stabilized with Portland Cement. International Journal of Geomatics and Geosciences, Vol. 5, No. 3.

Alengaram, U.J., Jumaat, M.Z. and Mahmud, H. (2008), Influence of cementitious materials and aggregate content on compressive strength of palm kernel shell concrete, Journal of Applied Sciences, Vol. 8(18), pp. 3207-3213.

Alengaram, U. J., Jumaat, M. Z., Mahmud, H., and Fayyadh, M. (2011), Shear behaviour of reinforced palm kernel shell concrete beams. Construction and Building Materials, Vol. 25, Issue 6, Pp. 2918-2927.

Aslam, M., Shafigh, P., and Jumaat, M.Z. (2017). High Strength Lightweight Aggregate Concrete using Blended Coarse Lightweight Aggregate Origin from Palm Oil Industry. Sains Malaysiana, Vol. 46, Issue 4, Pp. $667-675$.

Azunna, S. U. (2019), Compressive strength of concrete with palm kernel shell as a partial replacement for coarse aggregate. S. N. Applied Sciences, Vol.1, Paper 342.

BS EN 12390-5 (2000), Testing hardened concrete - Part 5: Flexural strength of test specimens, British Standard Institution, London, UK.

BS 8110 (1997), Structural use of Concrete: Part - 1: Code of Practice for Design and Construction. British Standards Institution, London, UK.

Busari, A., Oyedepo, J., Ofuyatan, O., Nurain, S., Ajayi, S., and Oti, M.N. (2018). Sustainability in Road Construction: Using Bamboo Straw Ash to Improve the Index Properties of Lateritic Soil. European Journal of Sustainable Development, Vol. 7, Issue 1, Pp. 89 - 97.

Chai, L.J., Shafigh, P., Mahmud, H., and Aslam, M. (2017). Effect of Substitution of Normal Weight Coarse Aggregate with Oil-Palm-Boiler Clinker on Properties of Concrete. Sains Malaysiana, Vol. 46, Issue 4, Pp. $645-653$.

Chungsangunist, T., Gheewla, H., and Patumsawad, S., (2009). Emission Assessment of Rice Husk Combustion for Power Production. World Academy of Science, Engineering and Technology Journal. Vol. 53, Pp $1070-1075$.

CIB and UNEP-IETC. (2002), Agenda 21 for Sustainable Construction in Developing Countries: A discussion document, WSSD Edition. Published by the CSIR Building and Construction Technology, Pretoria, South Africa.

Dwivedi, V.N., Singh, N.P., Das, S.S.., and Singh, N.B. (2006). A New Pozzolanic Material for the Cement Industry: Bamboo Leaf Ash. International Journal of Physical Sciences, Vol. 1 (3), Pp. 106 - 111.

Hoffman, A. J., and Henn, R. (2008), Overcoming the social and psychological barriers to green building. Organisation and Environment, Vol. 21, Pp. 390-419.

Kabir, S., A-Shayeb, A., and Khan, I. M. (2016), Recycled Construction Debris as Concrete Aggregate for Sustainable Construction Materials. ScienceDirect, Procedia Engineering, Vol. 145, Pp. 1518-1525.

Ling, F. Y. Y., and Gunawansa, A. (2011), Strategies for potential owners in Singapore to own environmentally sustainable homes. Engineering, Construction and Architectural Management, Vol. 18, Pp. 579-594. 
Mo, K. H., Yap, K. H. Q., Alengaram, U. J., and Jumaat, M. Z. (2014), The effect of steel fibres on the enhancement of flexural and compressive toughness and fracture characteristics of oil palm shell concrete. Construction and Building Materials, Vol. 55, Pp. 20-28.

Ndoke, P. N. (2006), Performance of palm kernel shells as a partial replacement for coarse aggregate in asphalt concrete, Leonardo Electronic Journal of Practices and Technologies, Vol. 5(9), pp. 145-52.

Okusami, J. I. (2019), Flexural and Shear Behaviour of Reinforced Rectangular Concrete Beams with Palm Kernel Shell Partially Replacing Granite as Coarse Aggregate. MEng. Thesis, Department of Civil Engineering, Federal University of Technology, Akure, Ondo State, Nigeria.

Olonode, K.A. (2010). Prospect of Agro-By-Products as Pozzolans in Concrete for Low-Cost Housing Delivery in Nigeria. Proceedings of the International Conference of the Obafemi Awolowo University, Faculty of Technolgy. Vol. 1, Pp. $217-221$.

Osei, D.Y. and E.N. Jackson (2012).Experimental Study on Palm Kernel Shells as Coarse Aggregate in Concrete. International Journal of Scientific and Engineering Research, vol. 3, issue 8, pp.1-6.

Perez-Lombard, L., Ortiz, J., and Pout, C. (2008), A review on buildings energy consumption information. Energy and Buildings, Vol. 40, Pp. 394-398.

Safinia, S., Al-Hinai, Z., Yahia, H. A. M., and Abushammala, M. F. M. (2017), Sustainable Construction in Sultanate of Oman: Factors Effecting Materials Utilization. ScienceDirect, Procedia Engineering, Vol. 196, Pp. 980-987.

Salau, M.A., Ikponmwosa, E.E., and Olonode, K.A. (2012). Structural Strength Characteristics of Cement/Cassava Peel Ash Blended Concrete. Journal of Civil and Environmental Research. IISTE. Vol. 2, No. 10, Pp. 68-77.

Shafigh, P., Jumaat, M. Z., Mahmud, H. B. and Anjang, N. A. H. (2012), Lightweight concrete made from crushed oil palm shell: Tensile strength and effect of initial curing on compressive strength, Construction and Building Materials, Vol. 27, pp. 252-258.

Short, A, and W. Kinniburgh, (1978), Lightweight Concrete, 3rd ed. London: Applied Science.

Slowik, M. (2014), Shear failure mechanism in concrete beams. ScienceDirect, Procedia Materials Science, Vol. 3 , Pp. 1977-1982. 